\title{
Recent Trends in Survival of Testicular Cancer Patients - Nation-wide Population Based Study
}

\section{Súčasné trendy preživania pacientov s nádorom testis - Národná populačná štúdia}

\author{
Ondrus D. ${ }^{1}$, Ondrusova M. ${ }^{2}$, Suchansky M. ${ }^{2}$ \\ ${ }^{1} 1^{\text {st }}$ Department of Oncology, Comenius University Faculty of Medicine and St. Elisabeth Cancer Institute in Bratislava, Slovak Republic \\ 2 Pharm-In Ltd., Bratislava, Slovak Republic
}

\begin{abstract}
Summary
Introduction and Aim: Survival of germ cell testicular cancer (TC) patients is better than for other malignancies and has not yet been exactly studied in the Slovak Republic. The aim of the study, based on the analyses of epidemiological data over time, was to present 5-year survival trends for germ cell TC patients. Patients and Methods: Survival is assessed within the framework of a nation-wide retro-prospective study among TC patients newly diagnosed between 1993-2007 (divided to three 5-year periods according the time of diagnosis - 1993-1997, 1998-2002 and 2003-2007). Standardized 5-year survival rates were calculated and compared between the periods using a widely accepted methodology. TC patients were divided into two groups (seminomas and non-seminomas histopathologically) and to two groups according the age at diagnosis ( $<40$ vs. $\geq 40$ years). The demographic characteristics of TC patients were analyzed using descriptive statistics. Statistical analysis was carried out using Microsoft Excel 2013, statistical software STATISTICA and Joinpoint Regression Programe, Version 4.3.1.0. Results: Five-year survival of TC patients $(n=2.748)$ diagnosed from 1993 to 2007 was $92.21 \%$. TC patients diagnosed between 1993 and $1997(n=810)$ reached 5 -year survival at $91.23 \%$, between years 1998 and $2002(n=916)$ at $92.14 \%$ and between years 2003 and $2007(n=1.022)$ at $93.05 \%$. There was not a statistically significant difference in survival among these three 5 -year periods. Significant difference in 5-year survival was observed between seminomas and non-seminomas in each 5 -year period. Compared with younger patients (age $<40$ years), there was a significantly worse survival for TC patients (age $\geq 40$ years) in all groups. Conclusion: Moderate improvement in survival for TC patients in the Slovak Republic is probably influenced by diagnostic and therapeutic progress, including multidisciplinary care and patient's concentration in specialized centers. The long-term follow-up of TC survivors can also help to prevent late side effects of the treatment modalities and to detect second malignancies.
\end{abstract}

Key words

testicular cancer - seminoma - non-seminoma - age at diagnosis - survival
The authors declare they have no potential conflicts of interest concerning drugs, products, or services used in the study.

Autoři deklarují, že $v$ souvislosti s predmětem studie nemaji žádné komerční zájmy.

The Editorial Board declares that the manuscript met the ICMJE recommendation for biomedical papers.

Redakční rada potvrzuje, že rukopis práce splnil ICMJE kritéria pro publikace zasílané do biomedicínských časopisů.

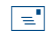

prof. Dalibor Ondrus, MD, DrSc.

$1^{\text {st }}$ Department of Oncology

Comenius University Faculty of

Medicine

St. Elisabeth Cancer Institute in

Bratislava

Heydukova 10

81250 Bratislava

Slovak Republic

e-mail: dalibor.ondrus@ousa.sk

Submitted/Obdrženo: 20. 12. 2017

Accepted/Přijato: 23. 1.2018

doi: 10.14735/amko2018137

\section{Acknowledgement}

The authors thank the heads of the departments of urology, oncology and pathology in the Slovak Republic for their cooperation.

Autori d’akujú vedeniu oddelení urológie, onkológie a patológie v Slovenskej republike za ich spoluprácu. 


\begin{abstract}
Souhrn
Úvod: Prežívanie pacientov s germinatívnymi nádormi testis je lepšie ako u iných malígnych ochorení, avšak doteraz nebolo v Slovenskej republike exaktne analyzované. Táto štúdia založená na analýze epidemiologických dát prezentuje vývoj časových trendov 5-ročného prežívania pacientov s testikulárnymi nádormi. Pacienti a metódy: Prežívanie pacientov s nádormi testis diagnostikovanými v rokoch 1993-2007 (rozdelenými do troch periód 1993-1997, 1998-2002 a 2003-2007) sa hodnotilo v rámci celonárodnej retroprospektívnej štúdie. Štandardizované 5-ročné preživanie bolo analyzované pomocou všeobecne akceptovanej metodológie. Pacienti boli tiež rozdelení do dvoch skupín podla histologického typu nádoru (seminómy vs. neseminómy) a na dve skupiny podla veku v čase diagnózy nádoru ( $<40$ vs. $\geq 40$ rokov). Demografické charakteristiky pacientov so všetkými typmi germinatívnych nádorov testis (okrem spermatocytárneho seminómu) sa podrobili deskriptívnej analýze. Údaje sa analyzovali pomocou programového vybavenia Microsoft Excel 2013, STATISTICA 12, Joinpoint Regression Program, Version 4.3.1.0. Výsledky: Celkové 5-ročné prežívanie všetkých pacientov s testikulárnym nádorom $(n=2,748)$ diagnostikovaným v rokoch 1993-2007 v Slovenskej republike bolo 92,21 \%. Títo pacienti boli rozdelení do troch skupín podla 5-ročných periód. Pacienti v perióde rokov 1993-1997 ( $\mathrm{n}=810)$ dosiahli 5-ročné prežívanie v $91,23 \%$, v perióde rokov 1998-2002 $(n=916)$ v 92,14 \% a v perióde rokov 2003-2007 $(n=1,022)$ v 93,05\%. V jednotlivých 5-ročných periódach neboli zaznamenané štatisticky významné rozdiely v celkovom prežívaní pacientov. Štatisticky významné rozdiely v 5-ročnom prežívaní sa preukázali medzi histologickými typmi nádorov (seminóm vs. neseminóm). Vo všetkých periódach rokov sa prejavil štatisticky významný rozdiel v 5-ročnom prežívaní podla veku v čase diagnózy nádoru ( $<40$ vs. $\geq 40$ rokov) v prospech mladších pacientov. Záver: Mierne zlepšovanie prežívania pacientov $s$ testikulárnym nádorom v Slovenskej republike je pravdepodobne spôsobené progresom v diagnostických a liečebných postupoch, vrátane multidisciplinárnej starostlivosti, a tiež koncentrácia pacientov do špecializovaných centier. Dlhodobé sledovanie prežívajúcich pacientov môže ovplyvnit’ rozsah neskorých vedlajších účinkov liečby a detegovat' sekundárne malignity.
\end{abstract}

Klúčové slová

nádor testis - seminóm - neseminomatózny nádor - vek v čase diagnózy - prežívanie

\section{Introduction}

Testicular cancer (TC) offers challenges due to its unique descriptive epidemiology and unknown etiology. Despite its relatively rare occurrence and high curability, it is the most commonly diagnosed malignancy among males aged 15-44 in developed countries. Moreover, its incidence has been increasing to epidemic proportions while mortality is decreasing in many countries $[1,2]$. Information on survival of cancer patients is an important indicator of cancer control. Survival information is needed for estimating how many cancer survivors are alive at any time in order to plan health services [3]. Survival for TC patients is better than for all other malignant diseases (excluding non-melanoma skin cancers), but significant differences worldwide have been documented [4].

With modern therapeutic approaches, 5 -year survival after diagnosis of TC exceed $90 \%$ in many European countries [5].

The survival for TC patients in the Slovak Republic has not yet been particularly and exactly studied. Therefore, this nation-wide study, based on the analyses of epidemiological data over time presents 5-year survivals. In addition, this paper discusses possible factors accounting for these trends and compares national data to the international context.

\section{Patients and Methods}

\section{Study design and data collection}

Survival is assessed within the frame-

work of a nation-wide retro-prospective study among patients with germ cell TC diagnosed between 1993-2007 (divided to three periods of diagnosis 1993-1997, 1998-2002 and 2003-2007). There were analyzed data from the medical records of patients with newly diagnosed germ cell TC, where the histology of the removed testis was primarily evaluated, consulted or revised by the only pathologist, specialist in the morphology of TC in the Slovak Republic. Patients with non-germ cell TC and with spermatocytic seminoma were not included in this study. TC patients were divided into seminomas and non-seminomas histologically and to two groups according the age at diagnosis ( $<40$ vs. $\geq 40$ years). The analyzed database of germ cell TC comprised 2.748 of all 2.978 TC cases. The newly diagnosed cases in the database are fully representative as a national source of incidence data of TC in the Slovak Republic $[6,7]$. The database contains personal data on patients, data describing cancer and other diagnostic and histopathologic findings, basic data on patient's treatment, as well as data on post-treatment follow-up. The starting point of the evaluation of survival time was defined as the date of the first diagnosis (morphological verification of germ cell $\mathrm{TC}$ ); the closing date was defined as the date of the end of follow-up (December $15,2017)$ or the date of patient's death.

\section{Statistical analysis}

Standardized 5-year relative survival rates were calculated on the basis of a widely accepted methodology, using computer program package Microsoft Excel 2013, STATISTICA 12 (data analysis software system) (Stat Soft, Inc.) [8] and Joinpoint Regression Program, Version 4.3.1.0. Recently proposed period analysis was applied to calculate survival in the latest period with accessible data [9].

The demographic characteristics of all patients were analyzed using descriptive statistics. Survival curves were generated using the method of Kaplan and Meier. The multiple-sample test implemented in Survival Analysis is an extension (or generalization) of Gehan's generalized Wilcoxon test, Peto and Peto's generalized Wilcoxon test, and the log-rank test. By this method, a score is first assigned to each survival time using Mantel's procedure. Next, a Chi-square value is computed based on the sums (for each group) of this score. If only two groups are specified, then this test is equivalent to Gehan's generalized Wilcoxon test, and the computations will default to that test in this case. All statistical tests were 
two-sided, and statistical significance was set at a $p<0.05$. Mann Whitney $\mathrm{U}$ Test was used for comparing median age of two main histological types of TC (seminoma vs. non-seminoma).

\section{Results}

The median age of all 2.748 germ cell TC patients in the period of 1993-2007 at the time of diagnosis was 31.97 years (95\% $\mathrm{Cl} 32.47-33.21$; interquartile range (IQR) 26.13-38.80; standard deviation (SD) 9.83). Average annual percentage change (AAPC) of the median age at the time of diagnosis was not significantly different (increase from 31.38 years (1993) to 32.79 years $(2007))(p>0.05)$, it was $+0.08 \%$ (difference between 1993 and 2007 was $+4.48 \%$ ), SD increased from 9.37 (1993) to 10.42 (2007).

The median age of 1.213 patients with pure seminoma testis was 35.83 years (95\% Cl 36.34-37.36; IQR 30.37-42.26; SD 9.08). The median age of 1.535 patients with non-seminoma testis was 28.46 years $(95 \% \mathrm{Cl} 29.22-30.15$; IQR 23.45-34.79; SD 9.22). Significant difference was observed between the age of patients with pure seminoma testis vs. non-seminoma testis $(p<0.001)$ (Tab. 1).

Five-year overall survival (OS) for all 2.748 germ cell TC patients diagnosed in the period of 1993-2007 reached $92.21 \%$ (95\% Cl 91.21-93.22). Five-year survival of TC patients diagnosed between years 1993-1997 $(n=810)$ reached $91.23 \%$ (95\% Cl 89.28-93.19), between years 1998-2002 $(\mathrm{n}=916)$ it reached $92.14 \%$ (95\% Cl 90.39-93.89) and between years 2003-2007 $(n=1.022)$ reached $93.05 \%$ (95\% Cl 91.49-94.61). The difference in survival between 5 -year periods was not statistically significant ( $p>0.05$ ) (Tab. 2).

Compared with younger patients (age $<40$ years), higher diagnostic age ( $\geq 40$ years) was associated with declined 5-year survival for TC patients ( 93.70 vs. $86.78 \%)$ in the time period of 1993-2007 (Tab. 3, Graph 1).

Five-year survival for patients with non-seminoma testis from the cohort of years 1993-1997 $(n=438)$ reached $89.50 \%$ (95\% Cl 86.62-92.38), from the cohort of years $1998-2002(n=538)$ reached $89.41 \%$ (95\% Cl 86.80-92.01) and from the cohort of years 2003-

Tab. 1. Age difference of patients at the TC diagnosis according to the histological types (seminoma, non-seminoma).

\begin{tabular}{l|c|c|c|c|c|}
\hline $\begin{array}{l}\text { Period } \\
\text { 1993-2007 }\end{array}$ & Mean & 95\% Cl & Median & IQR & p \\
\hline $\begin{array}{l}\text { non-seminoma } \\
\text { seminoma }\end{array}$ & 26.68 & $29.22-30.15$ & 28.46 & $23.45-34.79$ & $\mathrm{p}<0.001$ \\
\hline
\end{tabular}

TC - testicular cancer, IQR - interquartile range

Tab. 2. Five-year survival for TC patients by year periods and histological type.

\begin{tabular}{|l|c|c|c|c|}
\hline & $\mathbf{1 9 9 3 - 1 9 9 7}$ & $\mathbf{1 9 9 8 - 2 0 0 2}$ & $\mathbf{2 0 0 3 - 2 0 0 7}$ & $\mathbf{1 9 9 3 - 2 0 0 7}$ \\
\hline germ cell TC & $\mathbf{9 1}(89-93)$ & $\mathbf{9 2}(91-94)$ & $\mathbf{9 3}(91-94)$ & $\mathbf{9 2}(91-93)$ \\
\hline seminoma & $\mathbf{9 3}(91-94)$ & $\mathbf{9 6}(94-97)$ & $\mathbf{9 6}(95-97)$ & $\mathbf{9 5}(93-96)$ \\
\hline non-seminoma & $\mathbf{9 0}(87-92)$ & $\mathbf{9 0}(87-92)$ & $\mathbf{9 0}(88-93)$ & $\mathbf{9 0}(88-91)$ \\
\hline
\end{tabular}

TC - testicular cancer

Data are \% relative survival $(95 \% \mathrm{Cl})$.

Tab. 3. Five-year survival for TC patients by age groups and year periods.

\begin{tabular}{|l|l|l|l|c|c|}
\hline Periods & \multicolumn{2}{c}{$\begin{array}{c}\text { Survival of patients } \\
\text { in the age }<\mathbf{4 0} \text { years }\end{array}$} & \multicolumn{2}{c}{$\begin{array}{c}\text { Survival of patients } \\
\text { in the age } \mathbf{2 4 0} \text { years }\end{array}$} & p \\
\hline $1993-1997$ & $612 / 658$ & $93.01 \%$ & $127 / 152$ & $83.55 \%$ & $<0.001$ \\
\hline $1998-2002$ & $688 / 730$ & $94.25 \%$ & $156 / 186$ & $83.87 \%$ & $<0.00001$ \\
\hline $2003-2007$ & $722 / 770$ & $93.77 \%$ & $229 / 252$ & $90.87 \%$ & $>0.05$ \\
\hline $1993-2007$ & $2,022 / 2,158$ & $93.70 \%$ & $512 / 590$ & $86.78 \%$ & $<0.00001$ \\
\hline
\end{tabular}

TC - testicular cancer

$2007(n=559)$ reached $90.16 \%(95 \% \mathrm{Cl}$ 87.68-92.64). The difference in survival between these cohorts was not statistically significant ( $p>0.05$ ) (Graph 2).

Five-year survival for patients with seminoma testis from the 1993-1997 cohort $(\mathrm{n}=372)$ reached $93.28 \%(95 \% \mathrm{Cl}$ 90.72-95.84), from the 1998-2002 cohort $(\mathrm{n}=363)$ it reached $96.03 \%(95 \%$ Cl 94.05-98.01) and for the 2003-2007 cohort $(n=463)$ it reached $96.54 \%(95 \%$ $\mathrm{Cl}$ 94.87-98.21). The difference in survival between these cohorts was not statistically significant ( $p>0.05$ ) (Graph 3).

Five-year survival was in these three cohorts higher for seminoma testis (93.28, 96.03 and $96.54 \%$, resp.) than for non-seminoma testis $(89.50,89.41$ and
$90.16 \%$, resp.). There was a statisticaIly significant difference in survival between histological types in years 19932007 ( $p$ < 0.05) (Graph 4).

\section{Discussion}

Survival of patients having (not only) TC depends on multiple factors, such as the effectiveness of treatment, diagnostic practice, follow-up of the patients, methods of data collection and analysis, characteristics of patients (such as age, comorbidity) and cancer (such as clinical stage, histologic type). The increase in survival and the decrease in mortality are attributed to the introduction of cisplatin-containing chemotherapy, which has proven to be the most effective 


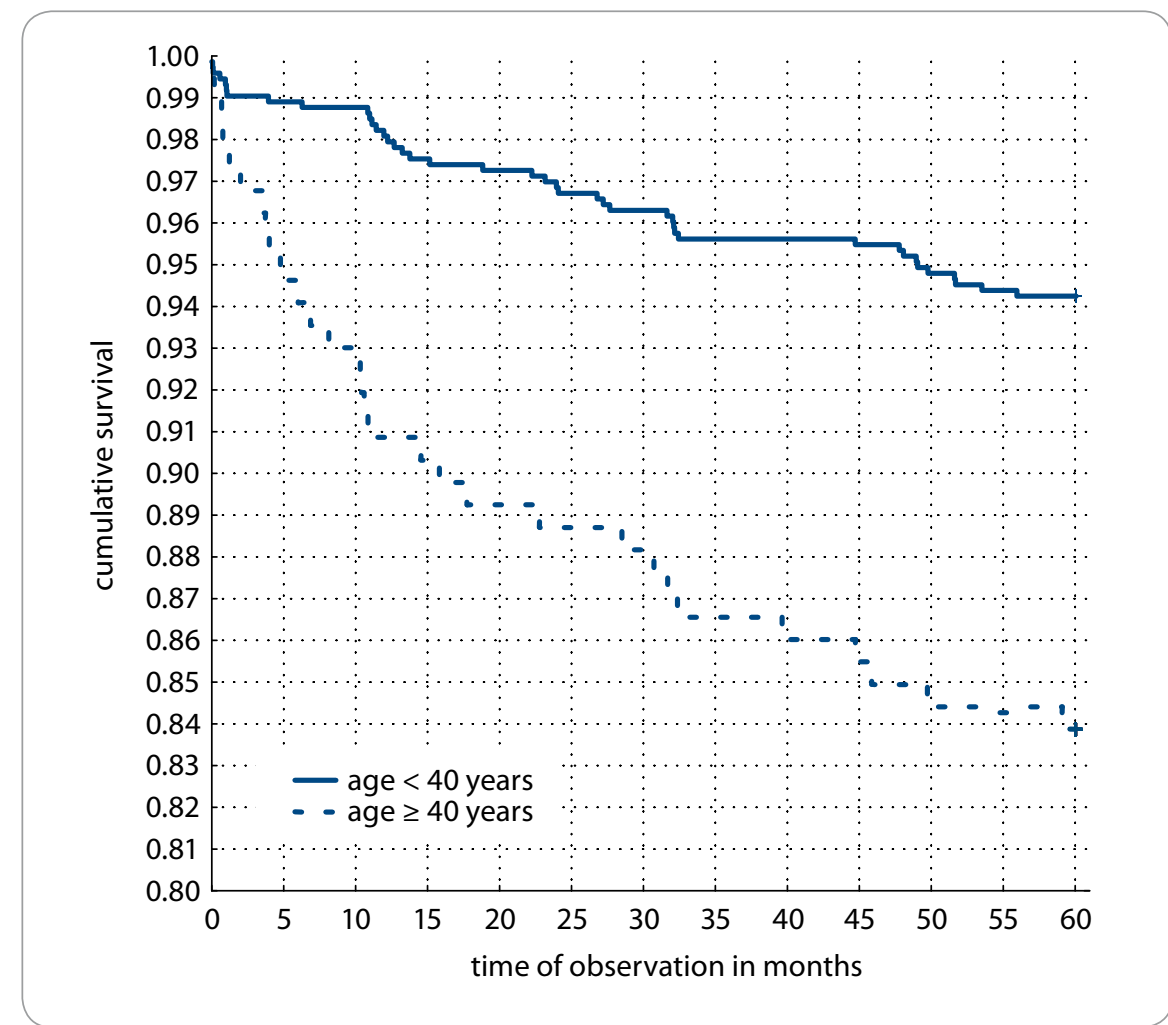

Graph 1. Five-year survival for TC patients by age groups.

TC - testicular cancer

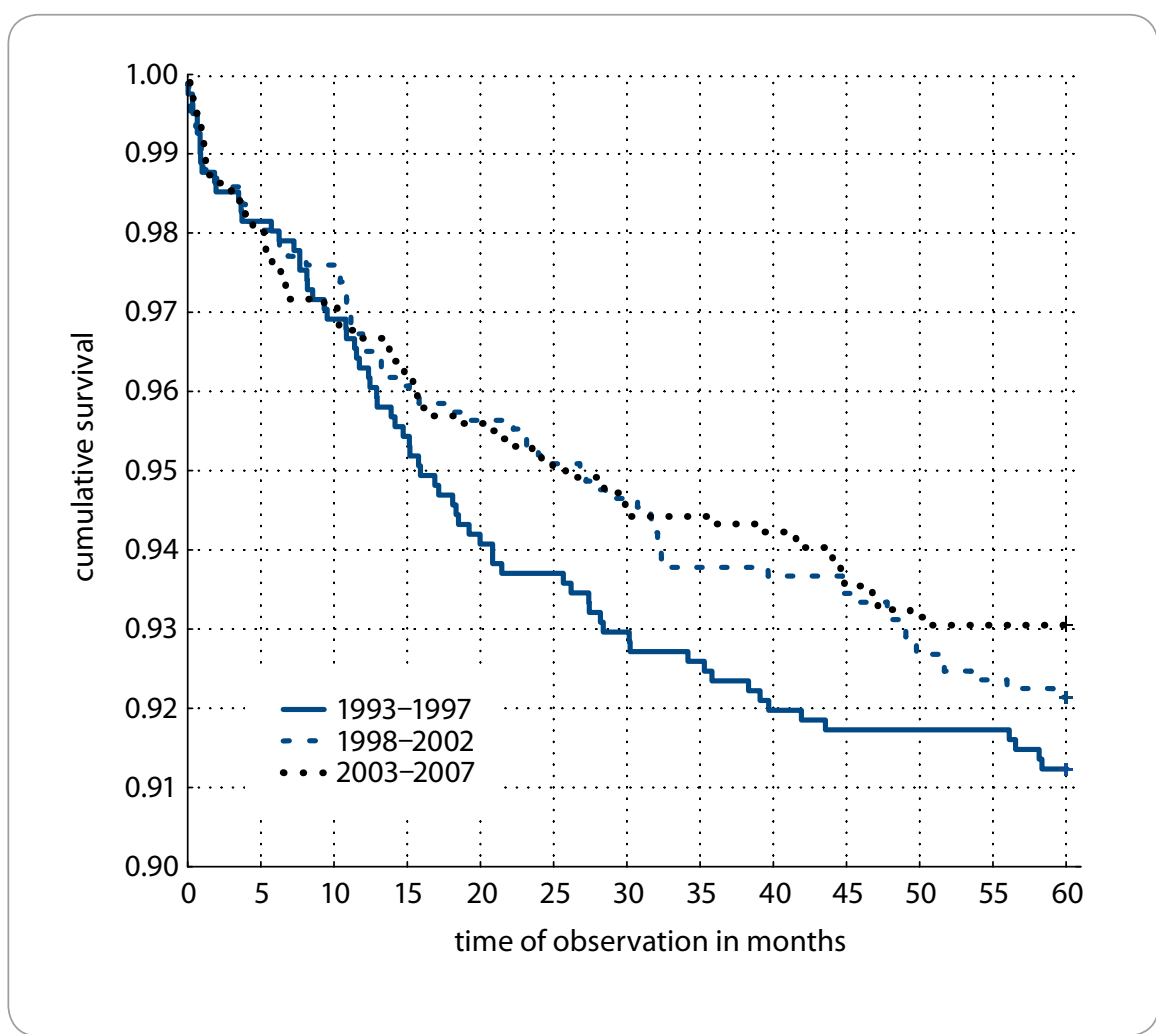

Graph 2. Five-year survival for TC patients according to year periods.

TC - testicular cancer treatment for non-seminomas [10]. Improved survival is also the result of the use of more effective imaging techniques, the introduction of appropriate serum tumor markers (STM), which allow for careful follow-up, and modification of surgical techniques [11]. Another explanation of the improved survival is a shift toward seminomas, which have a better prognosis than non-seminomas. Prognosis is also influenced by stage and age at diagnosis, with younger patients exhibiting better survival than older patients $[12,13]$.

Aareleid et al. [11] described the results of EUROCARE-2 study, where 5-year relative survival for TC diagnosed in 19851989 was between $90-95 \%$, which were observed in most participating countries of Northern, Western, Central and Southern Europe, and the United Kingdom. Five-year survival rate under $90 \%$ was seen in France (87\%), Slovenia (88\%), Poland $(83 \%)$, Slovakia (82\%) and Estonia (51\%). Rates in Poland, Slovakia and Estonia were significantly lower than the summary rate for Europe $(p<0.05)$. From 1978-1980 to 1987-1989, the 5-year relative survival rate for Europe increased from 79 to $93 \%(p<0.05)$

According to EUROCARE-3 [14], the European 5-year relative survival for TC diagnosed in 1990-1994 was 93\%. Survival differences across Europe were striking, with Estonia standing out for its exceptionally low age-standardized survival ( $71 \%$ at 5 years). Poland, Slovakia, Spain and Wales had survival just under the European mean (82-89\%), while other countries had 5-year survival $>93 \%$. Survival for TC decreases noticeably with advancing age. For patients aged 15-44 (age of the greatest incidence), 5-year relative survival was $94 \%$, whereas for patients aged 65-74, 5 -year survival was only $40 \%$. The main explanation for the differences in survival for TC across Europe is probably poor access to care of sufficient quality in low survival areas, resulting also in advanced stage at diagnosis. Survival for TC increased in most western European countries over the entire EUROCARE study period - from 1983-1985 to 19921994 - European 5-year relative survival improved from 89 to $95 \%$. While major 
improvements in chemotherapy or radiotherapy for TC have not been seen since cisplatin therapy was introduced at the end of the 70 s, the use of STM has made treatment monitoring and follow-up more precise.

According to EUROCARE-4 study in the period of 1995-1999, European 5 -year standardized relative survival for TC was $90 \%$ with generally small variation between countries [5].

Matsuda et al. [15] suggested an improvement in TC 5-year survival also in Japan from $89.6 \%(1993-1996)$ to $92 \%$ (1997-1999).

Results of EUROCARE- 5 population-based study [16] showed that the European mean age-standardized 5-year relative survival for TC (in patients aged 15-99 years) recorded in 2000-2007 was $88.6 \%$. Age standardized 5-year relative survival was $92.8 \%$ for TC patients from Northern Europe, $91.8 \%$ for those from Ireland/UK and from Central Europe, $89.1 \%$ for patients from Southern and $80.1 \%$ for patients from Eastern Europe. Age standardized 5-year relative survival was highest for patients from Sweden (94.6\%) and The Netherlands (93.5\%) and lowest for those from Bulgaria (71.7\%) and Lithuania (67.1\%). According to EUROCARE-5, age standardized relative survival for TC patients from the Czech Republic was $84.1 \%$ and from the Slovak Republic $90.7 \%$.

Our present study (1993-2007) showed better 5 -year OS of germ cell TC patients - 92.21\% compared with European mean [16]. Improvement of 5-year survival is shown between 1993 and 1997 (91.23\%), 1998-2002 (92.14\%) and 2002-2007 (93.05\%). It shows a clearly upward trend, and thus its total value in the Slovak Republic ranks it among the developed countries in Europe.

However, in some Baltic countries, the results were poorer, e.g. in Lithuania, it was only $71.2 \%$ in the same time-period [17]. Even despite the significant improvement in survival recorded in Estonia, the values of the 5-year relative survival in 2000-2004 are at a relatively low level, 74.5\% [18].

Worst trends of survival of TC patients in several countries of Europe (for example even in southern Portugal) may be

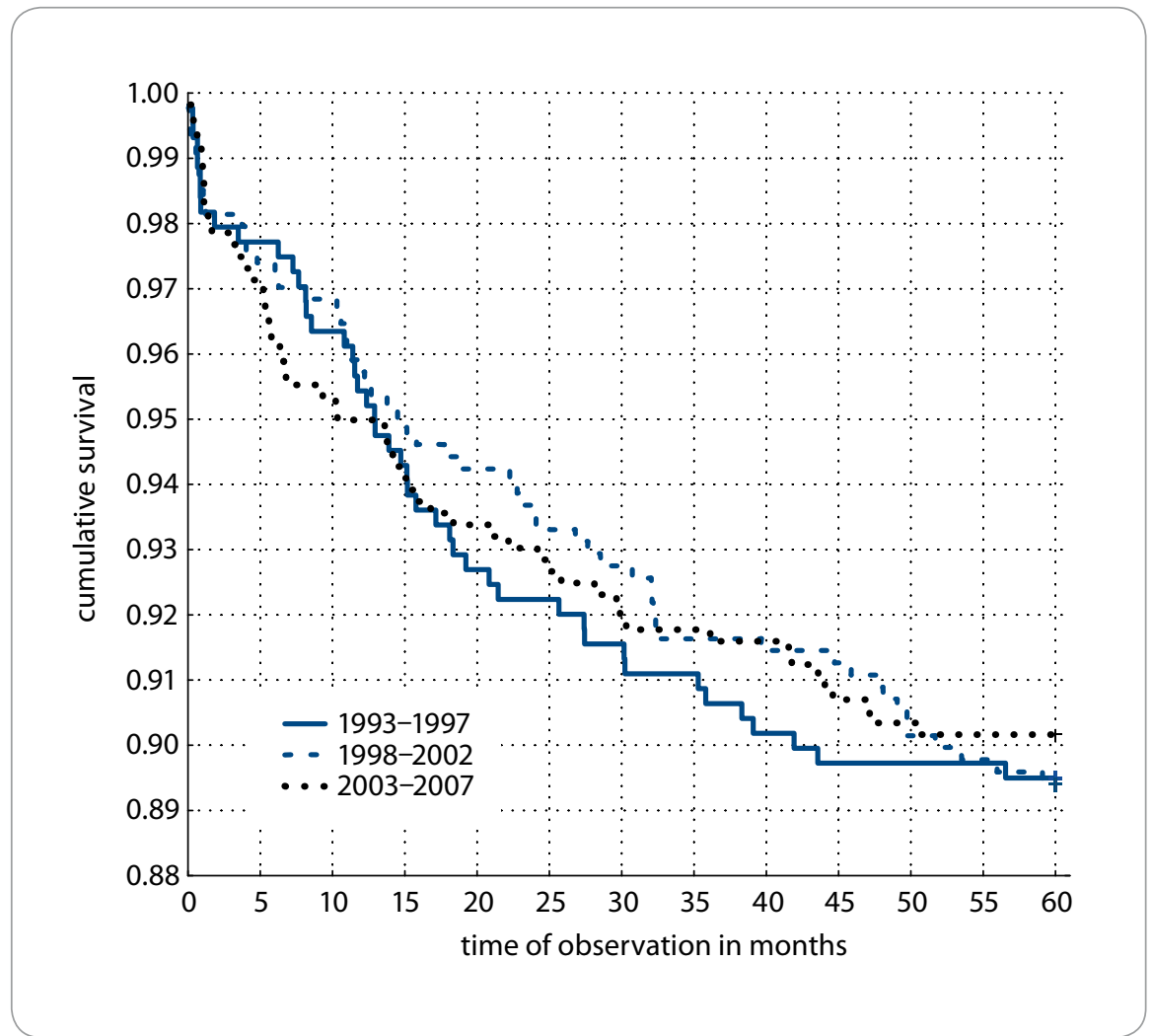

Graph 3. Five-year survival for patients with seminoma.

TC - testicular cancer

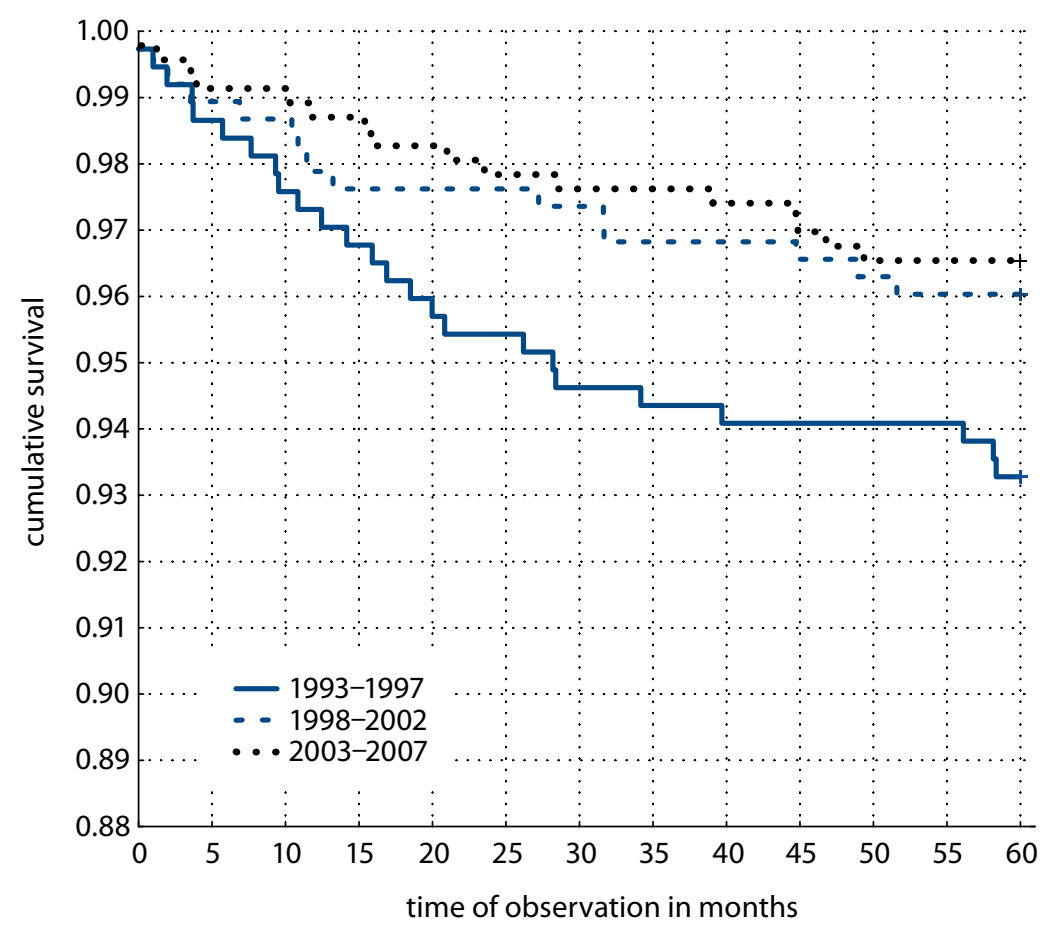

Graph 4. Five-year survival for patients with non-seminoma.

TC - testicular cancer 
dependent especially on TC diagnosis delay [19].

According to a Nordic study [20], the relative 5-year survival of TC patients in 1999-2003 is ranging from $88 \%$ in Finland to $94 \%$ in Sweden.

The recent Czech analysis showed a statistically significant improvement in the stage-adjusted relative survival of all TC patients between 2000-2004 (92.4\%) and 2005-2008 (94.4\%) [21]. Moreover, age standardized 5-year relative survival between time periods 20012005 (91.2\%) and 2006-2010 (92.7\%) improved as well [22].

According to published results of the framework of the EUNICE Survival Working Group [23], projections for 20052009 suggest that 5 -year relative survival will reach $90 \%$ in all cancer registries in Europe except Estonia, where survival is projected to be $82 \%$.

In the USA, the 5-year relative survival rate in whites, for all stages, was $95.8 \%$ for patients diagnosed 1992-1999, in blacks it was $86.9 \%$ [24].

Verhoeven et al. [25] observed improvement in relative survival rate in the Netherlands. TC 5-year survival improved from $95 \%$ in $1989-1993$ to $98 \%$ in 2004-2009.

Potential explanations for the age dependency of prognosis are reduced treatment intensity combined with increased therapy - related toxicity among older men $[3,26]$. In Germany, worse age specific 5-year relative survival for older patients with non-seminomas was observed (15-24 years 97.1\%, 45+ years 86.6\%) [3].

Compared with younger patients (age $<40$ years) diagnostic age ( $\geq 40$ years) was associated with declined 5-year OS for TC in our study (93.7 vs. $86.8 \%$ ) between 1993 and 2007.

\section{Conclusion}

The main factors contributing to survival improvement of TC patients are - interdisciplinary management involving staging (advances in diagnostic imaging), early treatment, attentive follow- -up and use of salvage treatments with concentration of TC patients in specialized centers [16]. An increasing concern is the observation that, life threatening conditions such as second malignancy and cardiovascular disease, occur more frequently in TC patients than in the general population. Long-term monitoring of TC survivors is necessary for possibility of the development of late side effects of the treatment modalities $[27,28]$.

\section{References}

1. Purdue MP, Devessa SS, Sigurdson AJ et al. International patterns and trends in testis cancer incidence. Int J Cancer 2005; 115(5): 822-827. doi: 10.1002/ijc.20 931.

2. Tamini R, Adami HO. Testicular cancer. In: Adami HO Hunter D, Trichopoulos D (eds). Textbook of cancer epidemiology. New York: Oxford University Press Inc; 2002 429-445.

3. Stang A, Jansen L, Trabert B et al. Survival after a diagnosis of testicular germ cell cancers in Germany and the United States, 2002-2006: A high resolution study by histology and age. Cancer Epidemiol 2013; 37(4): 492-497. doi: 10.1016/j.canep.2013.03.017

4. Berrino F, De Angelis R, Sant M et al. Survival for eight major cancers and all cancers combined for European adults diagnosed in 1995-99: results of the EU ROCARE-4 study. Lancet Oncol 2007; 8(9): 773-783. doi 10.1016/S1470-2045(07)70245-0.

5. Sant M, Allemani C, Santaquilani M et al. EUROCARE-4 Survival of cancer patients diagnosed in 1995-1999. Results and commentary. Eur J Cancer 2009; 45(6): 931-991. doi: 10.1016/j.ejca.2008.11.018

6. Ondrus D, Ondrusova M, Dusek L. Recent patterns in testicular cancer incidence, mortality and survival in the Slovak Republic with reference to international comparison. Cancer Invest 2012; 30(8): 545-551. doi: 10.3109/07357907.2012.700984.

7. Safaei-Diba C, Plesko I, Hlava P (eds). Cancer incidence in the Slovak Republic 2007. Bratislava: National Cance Registry of Slovakia, National Health Information Center 2012. 135

8. Hakulinen T, Abeywickrama KH. A computer program package for relative survival analysis. Comp Progr Biomed 1985; 19(2-3): 197-207.

9. Brenner $\mathrm{H}$, Gefeller $\mathrm{O}$, Hakulinen T. Period analysis fo up-to-date cancer survival data: Theory, empirical evaluation, computational realization and applications. Eur J Cancer 2004; 40(3): 326-335.

10. Verhoeven R, Houterman S, Kiemeney B et al. Testicular cancer: marked birth cohort effects on incidence and a decline in mortality in southern Netherlands since 1970. Int J Cancer 2008; 122(3): 639-642. doi: 10.1002/ijc.23061. 11. Aareleid T, Sant M, Hédelin G. Improved survival for patients with testicular cancer in Europe since 1978. Eur J Cancer 1998; 34(14 Spec. No): 2236-2240.

12. Sant M, Aareleid T, Artioli ME et al. Ten-year surviva and risk of relapse for testicular cancer: a EUROCARE high resolution study. Eur J Cancer 2007: 43(3): 585-592. doi: 10.1016/j.ejca.2006.11.006

13. Karim-Kos HE, De Vries E, Soerjomataram I et al. Recent trends of cancer in Europe: a combined approach of incidence, survival and mortality for 17 cancer sites since the 1990s. Eur J Cancer 2008; 44(10): 1345-1389. doi: 10.1016/j.ejca.2007.12.015.

14. Sant M, Aareleid T, Berrino F et al. EUROCARE-3: Survival of cancer patients diagnosed 1990-94 - results and commentary. Ann Oncol 2003; 13 (Suppl 5): v61-v118.

15. Matsuda T, Ajiki W, Marugame T et al. Population-based survival of cancer patients diagnosed between 1993 and 1999 in Japan: A chronological and international comparative study. Jpn J Clin Oncol 2011; 41(1): 4051. doi: $10.1093 / \mathrm{jjco} / \mathrm{hyq} 167$.

16. Trama A, Foschi R, Larrañaga $N$ et al. Survival of male genital cancers (prostate, testis and penis) in Europe 1999-2007. Results from the EUROCARE-5 study. Eur J Cancer 2015; 51(15): 2206-2216. doi: 10.1016/j. ejca.2015.07.027.

17. Juška A, Ulys A, Kaireviče L et al. Survival of patients with testicular cancer in Lithuania during 1999-2002. Medicina 2011; 47(1): 52-56.

18. Aareleid T, Gondos A, Brenner $\mathrm{H}$ et al. Testicular cancer survival in Estonia; improving but still relatively low. Acta Oncol 2011; 50(1): 99-105. doi: 10.3109/0284186X.2010.480981.

19. Passos-Coelho JL, Castro Ribeiro M, Santos E et al. Suboptimal survival of male germ-cell tumors in southern Portugal - a population-based retrospective study for cases diagnosed in 1999 and 2000. Ann Oncol 2011; 22(5): 1215-1220. doi: 10.1093/annonc/mda551.

20. Bray F, Klint A, Gislum M et al. Trends in survival of patients with male genital cancers in the Nordic countries 1964-2003 followed up until the end of 2006. Acta Oncol 2010; 49(5): 644-654. doi: 10.3109/02841860903575 315.

21. Pavlik T, Majek O, Büchler T et al. Trends in stage-specific population-based survival of cancer patients in the Czech Republic in the period 2000-2008. Cancer Epidemiol 2014; 38(1): 28-34. doi: 10.1016/j.canep.2013.11.002. 22. Uher M, Pavlik T, Majek O et al. On the importance of standardization in the assessment of populationbased cancer patient survival in the Czech Republic - methodology and results from the Czech National Cancer Registry. Klin Onkol 2014; 27(2): 127-135. doi: 10.14735/amko2014127.

23. Gondos A, Bray F, Hakulinen T et al. Trends in cancer survival in 11 European populations from 1990 to 2009: a model-based analysis. Ann Oncol 2009; 20(3): 564-573. doi: 10.1093/annonc/mdn639.

24. Biggs ML, Schwartz SM. Differences in testis cancer survival by race and ethnicity: a populationbased study, 1973-1999 (United States). Cancer Causes Control 2004; 15(5): 437-444. doi: 10.1023/B:CACO.00000 36443.95995 .40

25. Verhoeven RH, Karim-Kos HE, Coebergh JW et al. Markedly increased incidence and improved survival of testicular cancer in the Netherlands. Acta Oncol 2014; 53(3): 342-350. doi: 10.3109/0284186X.2013.819992.

26. Fossa, SD, Cvancarova M, Chen L et al. Adverse prognostic factors for testicular cancer -specific survival: A population-based study of 27,948 patients. J Clin Oncol 2011; 29(8): 963-970. doi: 10.1200/JCO.2010.32.3204.

27. Ondrus D, Ondrusova M, Friedova L. Second malignancies in long-term testicular cancer survivors. Int Urol Nephrol 2014; 46(4): 749-756. doi: 10.1007/s11255-0130554-4.

28. Kvammer $\varnothing$, Myklebust TÅ, Solberg A et al. Longterm relative survival after diagnosis of testicular germ cell tumor. Cancer Epidemiol Biomarkers Prev 2016; 25(5): 773-779 doi: 10.1158/1055-9965.EPI-15-1153. 